\title{
Форсайт финансовых
}

\section{профессий: бухгалтер и аудитор (итоги круглого стола)}

\author{
Кузубов Сергей Анатольевич, \\ доцент, факультет экономических наук / Департамент финансов \\ НИУ «Высшая школа экономики»
}

20 декабря 2016 г. на базе НИУ ВШЭ прошло первое мероприятие из серии круглых столов «Форсайт финансовых профессий», посвященное обсуждению будущих трендов и новых требований к профессиональной подготовке специалистов по бухгалтерскому учету и аудиту. Мероприятие было организовано Департаментом финансов факультета экономических наук НИУ ВШЭ совместно с Департаментом учета, анализа и аудита Финансового университета при Правительстве Российской Федерации при информационной поддержке АССА - глобальной ассоциации, объединяющей специалистов в области финансов и учета.

В круглом столе приняли участие ученые из ведущих российских вузов и практики высокого уровня представители Министерства финансов Российской Федерации, Федерального казначейства, Совета по профессиональным квалификациям финансового рынка, ИПБ России, партнеры KPMG, EY, PWC, представители крупного бизнеса и разного профиля работодателей. В режиме онлайн-конференции в работе круглого стола участвовали ученые из Санкт-Петербургского экономического университета, филиала НИУ ВШЭ в Санкт-Петербурге, Тюменского государственного университета.

Первый блок, вызвавший наиболее активную дискуссию на круглом столе, был посвящен трансформации профессии бухгалтера и аудитора под влиянием «фактора информатизации». Конструктивный тон дискуссии задал руководитель Департамента учета, анализа и аудита Финансового университета Р.П. Булыга, обозначивший, какие трудовые функции в области учета и аудита наиболее подвержены влиянию «фактора информатизации». Наиболее чувствительными (подверженными замещению IT-инструментами и программами), по его мнению, являются функции в области учета и аудита, связанные с выполнением типовых, повторяющихся (шаблонных) операций. В то время как функции в области учета и аудита, связанные с принятием управленческих решений, «профессиональным суждением», малочувствительны к «фактору информатизации». Профессор Р.П. Булыга полагает, что «трансформация функций в области учета и аудита под влиянием «фактора информатизации» будет обуславливать трансформацию профессии в сторону ее интеллектуализации, выработки профессионального суждения на основании анализа большого массива данных, подготавливаемых и обрабатываемых с помощью IT-инструментов и программ».

Дискуссию продолжили представители крупнейших аудиторских компаний, высказавшие ряд новаторских идей. Так, Антон Устименко, партнер практики аудиторских услуг ЕY, выразил мнение что для профессии аудитора необходима экспертиза не только в финансовых вопросах, но и понимание перспектив развития, современных технологий, оценки и управления рисками и возможностями. При этом продвинутая компьютерная грамотность и навыки программирования становятся базовым навыком любого работника финансовой области. Отсюда, как считает эксперт, вытекает предпочтительность привлечения в аудиторскую профессию кандидатов не с базовым экономическим, а с техническим образованием. Однако данное предложение не нашло широкой поддержки среди аудитории круглого стола и вызвало справедливые возражения о необходимости профильного высшего образования у лиц, занимающих руководящие должности в бухгалтерских службах и аудиторских организациях.

Второй блок дискуссии был посвящен изменению и расширению функций бухгалтера и аудитора при переходе к экономике с доминирующей интеллектуальной составляющей, ключевым ресурсом которой становятся не материальные, а интеллектуальные активы. Модератор данного блока С.А. Кузубов поставил вопрос о полезности традиционных финансовых отчетов в условиях, когда основные факторы создания стоимости не находят отражения в такой отчетности и остаются скрытыми от глаз основных категорий стейкхолдеров компаний. Одним из возможных решений данной проблемы является 
распространение интегрированной отчетности, позволявшей раскрывать более полно модель создания стоимости компании и ее воздействие на все группы заинтересованных лиц, а не только на инвесторов и кредиторов. В рамках такой отчетности традиционные финансовые показатели дополняются целым блоком нефинансовых показателей, характеризующих устойчивое развитие компании. Экспоненциальный рост количества таких отчетов в мире и Российской Федерации требует от бухгалтерской и аудиторской профессии нового, интегрированного мышления, которое в итоге приводит к изменению роли бухгалтера с поставщика информации на субъект создания стоимости. Вместе с тем, как отметили эксперты, сегодня мы имеем только ориентировочное представление о том, что собой представляет интегрированное мышление, и оно не может быть формализовано в виде необходимых умений и навыков трудовой функции. По мнению Л.3. Шнейдмана, директор Департамента регулирования бухгалтерского учета, финансовой отчетности и аудиторской деятельности Министерства финансов Российской Федерации, работа с интегрированной отчетностью не требует от бухгалтеров и аудиторов навыков, принципиально отличных от навыков, необходимых для обращения с традиционной финансовой отчетностью. При этом сама отчетность в области устойчивого развития является уделом узкого круга компаний и выступает для них больше средством PR, чем экономической целесообразностью. С такой позицией не согласился В.Ю. Скобарев, генеральный директор АО «ЭНПИ Консалт», заявивший о растущем спросе на услуги по независимому заверению нефинансовых отчетов со стороны широкого круга российских компаний.

Тему для обсуждения в третьем блоке задал В.И. Бариленко, заместитель руководителя по научной работе Департамента учета, анализа и аудита Финансового университета. Он заявил о необоснованности ограничения уровня квалификации бухгалтеров лишь 6-м уровнем, который соответствует компетенциям, обеспечиваемым средним профессиональным образованием и высшим образованием на уровне бакалавриата, а также о необоснованности ограничения цели профессиональной деятельности бухгалтеров лишь задачами финансового учета и формирования бухгалтерской (финансовой) отчетности. Была предложена новая формулировка цели профессиональной деятельности: «Формирование учетно-контрольной и аналитической информации, необходимой заинтересованным внутренним и внешним пользователям для принятия экономических решений». Данные предложения нашли положительный отклик у представителей университетов, в частности кафедры учета, анализа и аудита Тюменского государственно университета.

В продолжение дискуссии Вера Стародубцева, глава «АССА - Россия», рассказала о масштабном исследовании, проведенном АССА по всему миру, в отношении глобальных факторов изменений профессии.
При этом профессиональными компетенциями, необходимыми для успеха в будущем, станут, помимо предметных знаний и опыта, креативность, эмоциональный интеллект, концептуальное видение и цифровые технологии.

Последний, четвертый, блок круглого стола был посвящен вкладу работодателей в создание Дорожной карты развития профессии в России. Модератор блока В.П. Чая, профессор МГУ имени М.В. Ломоносова, в своем вдохновенном выступлении высказал смелую мысль о целесообразности слияния профессий бухгалтера и аудитора и выработки единого профессионального стандарта.

Л.И. Хоружий, президент ИПБ России, в своем выступлении рассказала о разработке ПС «Бухгалтер» и направлениях его совершенствования. Точку зрения работодателей на профессиональные компетенции бухгалтера высказали также представители компаний «Аэрофлот», «СТЕК», PWC.

Завершая дискуссию, один из организаторов и идейный вдохновитель круглого стола И.В. Ивашковская, ординарный профессор, руководитель Департамента финансов НИУ ВШЭ, выступила с предложением, во-первых, создать рабочую группу для обобщения конкретных рекомендаций Совету по профессиональным квалификациям; во-вторых, организовать на регулярной основе сетевой междисциплинарный научный семинар «Дорожная карта исследований в бухучете и аудите для России», цель которого - обобщение западных исследований в области бухгалтерского учета и аудита и анализ их релевантности для современной России, и вовлечь в него университеты Москвы, Санкт-Петербурга, регионов России с помощью онлайн-формата; и в-третьих, на базе Департамента финансов ФЭН НИУ ВШЭ создать регулярный сетевой межвузовский семинар «Измерения для нефинансовой отчетности» для обсуждения и обобщения методов измерений интеллектуальных ресурсов компаний и роли бухгалтера в ее формировании, разработать программу семинара и вовлечь в него университеты Москвы, Санкт-Петербурга, регионов России с помощью онлайн-формата.

Таким образом, по результатам круглого стола был поддержан курс на актуализацию ПС «Бухгалтер» в соответствии с реальными потребностями экономики России и уровневой системой профессиональной подготовки специалистов по учету, что должно послужить также стимулом для совершенствования связанных с учетом образовательных программ.

Медиаматериалы к выступлениям участников круглого стола представлены на официальном сайте Департамента финансов НИУ ВШЭ (https://economics. hse.ru/defin/ffp/). Приглашаем всех заинтересованных в развитии финансовых профессий к продолжению дискуссии по тематике круглого стола на постоянно действующем форуме:

http://forum.hse.ru/newforum/index.php?t=i\&cat=59\&S= 27a014510513d7cb01f6940a45eec477. 